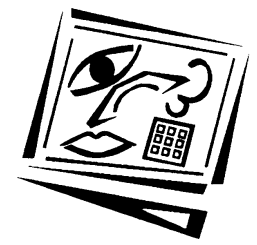

\title{
Leading change: Applying change management approaches to engage students in blended learning
}

\author{
Diana Quinn, Yousef Amer, Anne Lonie \\ University of South Australia
}

Kim Blackmore, Lauren Thompson, Malcolm Pettigrove

Australian National University

\author{
An Outstanding Paper Award recipient, ascilite Hobart 2011 Conference
}

\begin{abstract}
The Australian National University (ANU) and the University of South Australia (UniSA) have embarked on Federally-funded project to collaborate in the design, development and delivery of a range of undergraduate and postgraduate courses in engineering. The collaboration investigates new ways to bring together the strengths and discipline expertise of each institution to the students of both universities, utilising blended teaching and learning approaches. The collaboration brings much change - at the organisational level in the blending of programs, at the staff level in their approaches to teaching and at the students' level in their approaches and engagement with cross-institutional blended learning. This paper focuses on how change management principles were used to guide a systematic approach to engaging students into the learning culture associated with the Engineering Hubs and Spokes Project's theme - 'Advanced Collaboration for Excellence'.
\end{abstract}

\section{Introduction to Hubs and Spokes blended teaching and learning}

The Australian Government has funded a three-year 'Hubs and Spokes' project to explore processes and outcomes associated with advanced collaboration in teaching and learning in higher education. The vision is to allow students from 'spoke' universities, to study high quality courses offered collaboratively through specialist centres of excellence, called discipline 'hubs', while receiving credit towards their home degree (Trounson, 2011). A reciprocal 'Hubs and Spokes' collaboration model operates within the health and engineering disciplines of the Australian National University (ANU) and the University of South Australia (UniSA). The engineering component of the project involves collaboration in undergraduate course streams and co-development and delivery of new postgraduate and engineering internship programs. Courses are offered to students from both institutions in 'blended' mode.

\section{Components of the blend}

Blended teaching and learning is a cornerstone of our Engineering Hubs and Spokes collaboration, but, as 'blended' can be a uncertain term (Oliver \& Trigwell, 2005), it is important to unpack what we mean when we say 'blended'. There are several distinct components to the Hubs and Spokes blend; namely, course design and development, face to face and online teaching, and face to face and online learning and support for 
learners. The undergraduate course sharing arrangement in Hubs and Spokes allows students from UniSA to access a co-developed stream of courses involving renewable energies offered by ANU; similarly students from ANU are able to access manufacturing management stream of courses offered by UniSA (Blackmore, Compston, Kane, Quinn \& Cropley, 2010). A common learning management system platform, Moodle, simplified the process for cross-institutional course sharing (Kane \& Lonie, 2011).

It is important to appreciate that Hubs and Spokes course sharing is not outsourcing. Both streams of Hubs and Spokes courses have been collaboratively developed. This is the first level of blending - the blending of staff expertise, approaches and perceptions of teaching and learning in engineering. The second level of blending is that of delivery mode. The courses have been developed for technology-enhanced learning opportunities coupled with significant face to face learning experiences that are replicated at each institution with facilitation by on-the-ground academic staff. A third blend is achieved in Hubs and Spokes courses as students are required to collaborate across institutions. This collaboration provides penultimate and final year engineering students with opportunities to use reflection to develop advanced collaboration skills in relation to technology-enabled communication. As engineers, we appreciate that this experience will better prepare our graduates for the realities of professional life in global engineering firms and accessing continuing professional development opportunities available through technology-mediated communication (Kamrani \& Nasr, 2008; Sheppard, Macatangay, Colby, Sullivan \& Shulman., 2008).

The implementation of this project has brought much change to project staff, faculty and students. Our staff have learned how to collaborate with unfamiliar people, academic structures, policies and approaches and work together to enhance and deliver each other's approaches to teaching and learning. This has resulted in a productive and enriching collaboration that has had many positive spin-offs in our home institutions. What we hadn't fully appreciated until our first full evaluation round, was the extent that the students at both institutions would need to change their own familiar and largely successful ways of learning at university and embark on more flexible but often alien ways of learning, and how much support would be required by students to bring about this change.

\section{Manufacturing management course development}

In this section we focus on the systematic development, delivery and continuous improvement of the manufacturing management courses offered by UniSA to ANU further information about ANU courses offered to UniSA students is explained elsewhere (Blackmore et al., 2010).

\section{The original UniSA online course development}

Prior to the Hubs and Spokes collaboration, the UniSA manufacturing management courses had been taught as fully online courses through the School of Advanced Manufacturing and Mechanical Engineering to distance learners. Two of these courses, Intelligent Manufacturing Systems and Supply Chain Management G had been previously developed for fully online delivery using a systems engineering approach which consisted of considering the customers (in this case, the students), the various stakeholders (lecturers, IT staff, University, etc.) and requirements at the design onset (Amer, Ashraf, Luong, Lee \& Wang, 2007) using various analytical tools. Figure 1 
depicts a 'fishbone' cause and effect analysis of the our initial 'distance approach' to online learning, which identified limitations in the study material, delivery style, people involved and the information technology (IT) systems supporting course delivery, all of which had impacted on student engagement.

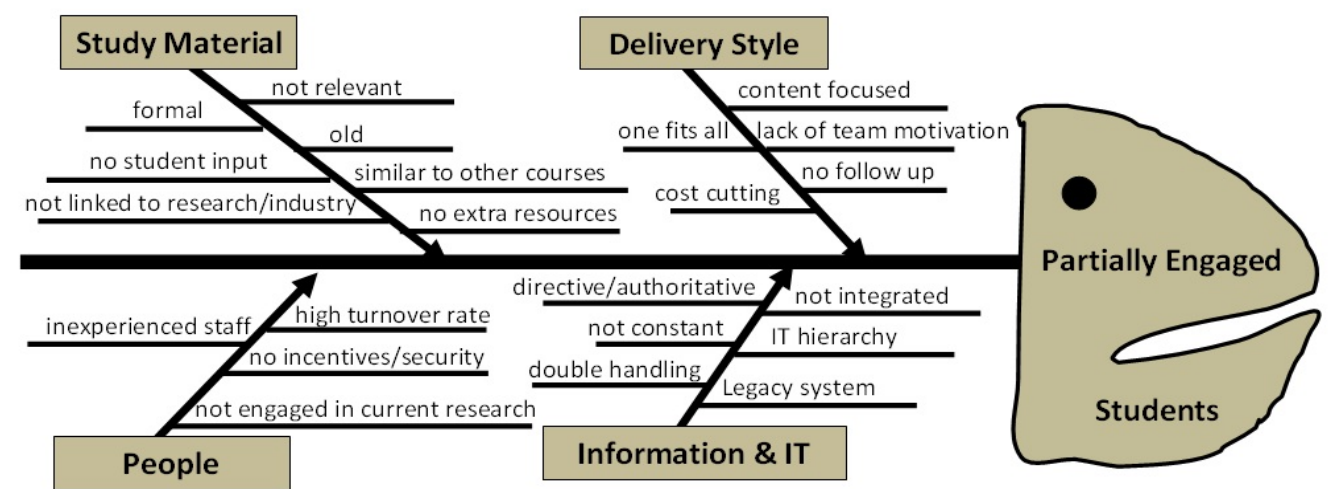

Figure 1: Fishbone analysis of traditional (distance) mode of online learning

These issues were addressed through incorporating Salmon's (2002) model of 5 stages to active online learning: access and motivation, online socialisation, information exchange, knowledge construction and development. Group work was developed through these stages and enabled students to become engaged and interactive. Course material was presented through a variety of means: recorded lectures with notes and slides; related research and industry articles; and teaching material made available through e-readers with links to related industrial sites. The course coordinators' delivery style aimed to motivate students to remain engaged by having a consistent online presence, communicating regularly to the students through forums, giving regular feedback about students' online work and quickly addressing any IT issues that arose. Student self-assessment was encouraged through the posting of an online solution file towards the end of the courses. The results of these enhancements to the online learning experience were evident in consistent positive student course evaluations.

\section{The change to Hubs and Spokes blended courses}

To commence the collaborative development of these successful online courses into the new blended mode for the Hubs and Spokes project, an online course portfolio was developed (Cerbin, 1994). Course portfolios included information about the current online delivery of the course such as:

- UniSA course information booklets - with the aims, objectives and assessments

- study guide and website

- text book and references

- staff homepages of the teaching team

- trend graphs of enrolment numbers

- trend graphs of student feedback collected over the previous three years using UniSA's standard student evaluation instrument

- current grade distribution data. 
The course portfolios were shared with all collaborators using an institutionallyneutral Hubs and Spokes website built on EdNA (Educational Network of Australia). EdNA provides free group web sites to Australian educators. Fortunately, EdNA was built on a Moodle platform, and thus also provided some early experience for our collaborators in using Moodle, which was the foundation of our newly-installed learning management systems at UniSA (learnonline) and ANU (Wattle) (Kane \& Lonie, 2011).

\section{Focus on staff and course re-development}

Prior to meeting with our colleagues at ANU, a scholarly peer review of blended learning environments was performed to help the UniSA teaching team articulate their teaching and learning conceptions and perceptions associated with these courses (Trigwell, Prosser \& Waterhouse, 1999; McKenzie et al., 2010). This reflection was also shared via the EdNA website. A workshop that was then organised between collaborators at UniSA and ANU to share perspectives and brainstorm enhancements to the course. Face to face activities (e.g. practicals or tutorials) that had been used successfully to support learning key concepts related to manufacturing engineering in courses at either institution were shared and the richest learning experiences selected and incorporated. The Teaching Options in learnonline planning and review document (LTU, 2010), which incorporated Chickering \& Gamson's principles of undergraduate teaching (1987), Ramsden's quality teaching (2007) and Biggs \& Tang's constructive alignment principles (2007), was used as a framework to consider student engagement using face to face and the new Moodle-based tools available to the teaching team. An action plan was agreed to, which was subsequently adapted into a project management document, called a Blended Learning Agreement. The artefacts from these workshops were shared via the course portfolio on the Hubs and Spokes EdNA website.

Course website development was conducted by project team members in conjunction with academic staff collaborators. Construction of the web site progressed well over the 3 month development phase, with weekly to fortnightly cross-institutional reviews of progress in relation to the Blended Learning Agreement, which were facilitated using technology. Scaffolded activities to introduce students to the range of new Moodlebased technologies used in the courses were designed and integrated. Formative evaluation of student experiences was integrated at weeks 3, 6 and 9 using simple surveys with minor adjustments made to the student experience on the fly. Summative evaluation, designed to evaluate student engagement, was conducted post-teaching by Hubs and Spokes team members not directly involved in the teaching and learning environment.

Initial evaluation of students through surveys, focus groups and interviews revealed that a proportion of the students studying manufacturing management courses just didn't get it - they did not perceive the value of Hubs and Spokes courses or learning in this new collaborative environment between two institutions. All they knew was that, despite enrolling in their home institution, they were being asked to do more and different things, which challenged their current approaches to learning. They felt the additional burden of needing to tackle this change in addition to mastering the new content. We were concerned that students were resisting change and adopting surface approaches to the online and face to face components of their blended learning (Ramsden, 1992). We realised that although we had transformed the teaching 
environment, and carefully considered the teachers' perceptions and conceptions of teaching and learning through workshops and collaborative course development opportunities, we had not focused enough on the student's perceptions and conceptions of the teaching and learning environment (Ramsden, 1992; Trigwell \& Prosser, 1991; Trigwell et al., 1999). As a result, we were asking the students to make significant changes to their approaches to learning, which they were resisting and this was negatively impacting on their engagement.

\section{Student engagement and its relationship to change}

In general, engagement can be expressed as

... a coming together, a merging, a fusing. Engagement points to mutual listening, to reciprocity, to dialogue, but conducted in a willingness to change. (Barnett, 2003, p.253; emphasis added)

The reference to change by Barnett is important. In Engineering Hubs and Spokes courses, students are required to change the way they learn, change their processes for learning, change their time and place of learning - as well as be prepared to learn new content with new people. Experiencing and becoming more confident online collaborators will better prepare our students for their new careers and will better shape their identities as engineers of the future (Kamrani \& Nasr, 2008; Sheppard et al., 2008).

Student engagement, or the 'time and energy students devote to educationally sound activities inside and outside of the classroom' (NSSE, 2007, p.3; emphasis added) can be seen as five somewhat overlapping but distinct benchmarks (Coates, 2006):

1. level of academic challenge - the students' chosen behaviour, did students work harder than anticipated to meet the challenge of change?

2. active and collaborative learning - opportunities for the social and intellectual dimensions - these can be individual experiences or collaborative, in discussion with peers, inside and out of the classroom, in person or virtual

3. student-faculty interaction - opportunities for mentoring, to observe discipline role models, to have informal learning conversations with staff

4. enriching educational experiences - opportunities for meaningful or significant learning experiences (other than in-course experiences)

5. supportive campus environment - how the environment around the students can make engagement in learning more likely to be the outcome.

Through surveys such as National Survey of Student Engagement (NSSE), the engagement of students has been used to provide measures of quality of university education. The indices examined in this survey look at both in-course learning and the environment that surrounds the learners. This examination of the whole student experience as a measure of engagement is very relevant when considering our Hubs and Spokes model of blended learning. We are creating a new teaching and learning culture that supports the creation of excellent learning environments through advanced collaboration. To properly engage students and staff in this process we needed to better share our vision and hope for the future and provide adequate support and encouragement, using in-course and out-of-course experiences, to bring about this change (Adams et al., 2011). 


\section{Using change management principles to re-engage learners for change}

The recognition that our Hubs and Spokes collaboration was actually a change process for students and that this involved not only the course but the culture that surrounds the course, we were encouraged to draw on scholarship related to change management to support our analysis and further development.

Simplistically, organisational change can be seen as three separate phases (Lewin, 1952):

1. unfreezing of the old culture and setting the stage for change,

2. making the change happen, and

3. re-freezing, to make the changes stick.

With regards to students transitioning to Hubs and Spokes blended learning, we needed to consider what preparation students had for undertaking our crossinstitutional blended courses, what support they were given for making the change, and what reinforcement the students needed to make the changes stick.

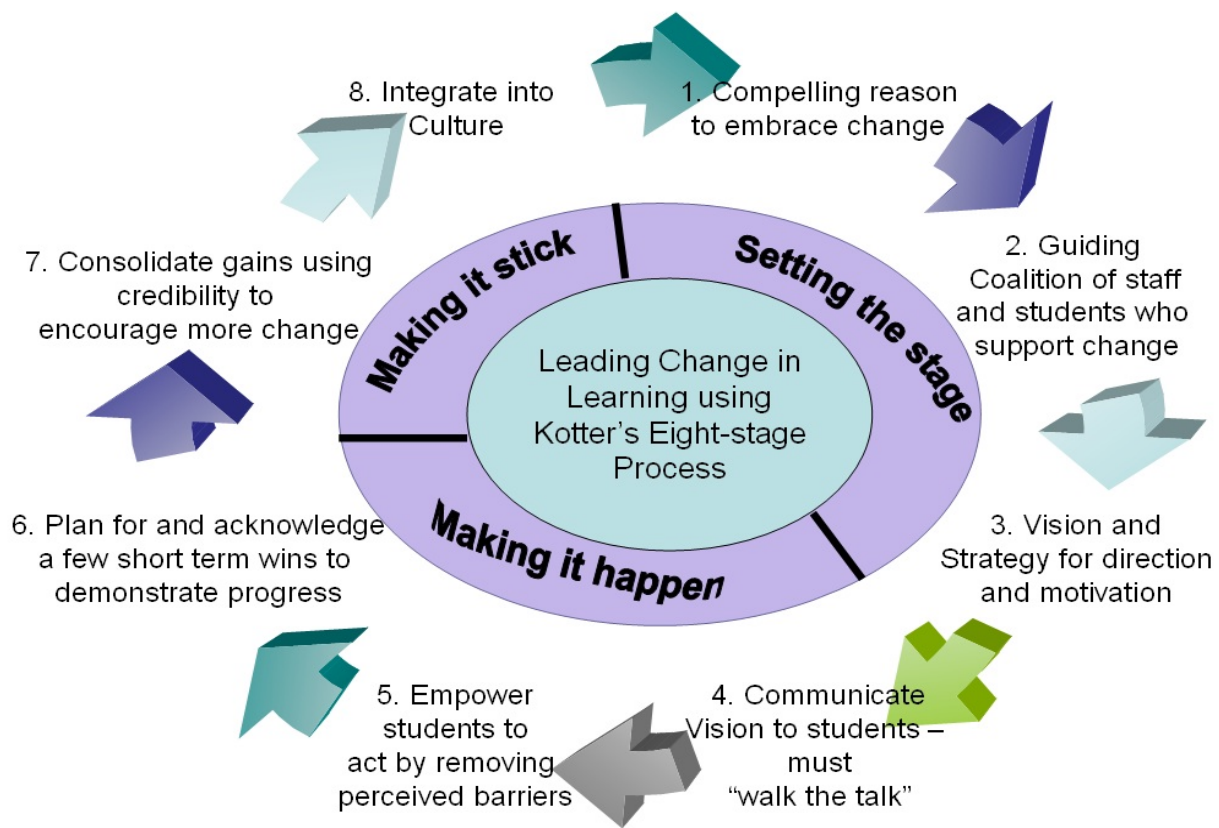

Figure 2: Leading change in learning using Kotter's eight-stage process

John Kotter analysed hundreds of change management attempts in large and small industries over 10 years and distilled his principles of change into eight strategic steps (Kotter, 1995; 2007). He found that all eight steps needed to be present and in the right order for the change process to be successful. Kotter acknowledged that these steps also take time, and warned that moving onto the next step before enough time has been spent on the preceding step will only give the illusion of progress. Kotter's framework has been used previously to guide faculty developers as change agents 
within university settings (Diamond, 2005; Dawson et al., 2010), to analyse the effectiveness of strategic change and innovation on staff in higher education in general (Carneiro, 2010) and in localised settings (Guzmán et al., 2011), and also for supporting students' transition from university to career (Heathcote et al., 2007). We propose that Kotter's steps can be used as a means to evaluate learning support for students to better engage them in the new approaches to learning that are afforded by blended learning.

When we utilised John Kotter's eight-step framework for leading change (Figure 2) to analyse our project, we found gaps, particularly in our support for students in transition to change. In our first iteration of these courses we had concentrated on the making it happen steps, using constructively aligned assessment (Biggs \& Tang, 2007) as our driver, but had seriously underdone the first three steps of setting the stage for change, and had also done minimal work to integrate the change into the culture of learning. By brainstorming as a project team, we were inspired by Kotter's framework to see new opportunities for future development of Hubs and Spokes courses that could ensure the long term survival of this change, by more holistically engaging students (Table 1).

Table 1: Leading change in learning - audit of student support for transition

\begin{tabular}{|c|c|c|}
\hline $\begin{array}{l}\text { Kotter's } \\
\text { framework } \\
\text { applied to } \\
\text { students }\end{array}$ & $\begin{array}{l}\text { What we had previously } \\
\text { done to support each stage }\end{array}$ & $\begin{array}{l}\text { What we are or planning to do to further scaffold } \\
\text { students' transition towards change }\end{array}$ \\
\hline \multicolumn{3}{|c|}{ Setting the stage } \\
\hline \multirow[t]{2}{*}{$\begin{array}{l}\text { 1. Establish a } \\
\text { compelling } \\
\text { reason to } \\
\text { embrace the } \\
\text { change }\end{array}$} & $\begin{array}{l}\text { New course learning } \\
\text { objectives related to advance } \\
\text { collaboration skills. }\end{array}$ & $\begin{array}{l}\text { Create a required induction experience that } \\
\text { includes the voices of industry leaders outlining } \\
\text { the reason for Hubs and Spokes type learning in } \\
\text { relation to the development of key skills for } \\
\text { employability in global companies. }\end{array}$ \\
\hline & $\begin{array}{l}\text { Hubs and Spokes courses and } \\
\text { how this will impact on their } \\
\text { learning. }\end{array}$ & $\begin{array}{l}\text { Create quizzes that require students to self assess } \\
\text { their understanding of what it means to study } \\
\text { Hubs and Spokes course as part of induction. }\end{array}$ \\
\hline \multirow[t]{2}{*}{$\begin{array}{l}\text { 2. Create a } \\
\text { guiding } \\
\text { coalition } \\
\text { who support } \\
\text { the change }\end{array}$} & $\begin{array}{l}\text { Academic staff and project } \\
\text { development staff work } \\
\text { together and co-present at } \\
\text { introductory sessions. }\end{array}$ & $\begin{array}{l}\text { Present within the induction the voices of senior } \\
\text { researchers and academics staff explaining the } \\
\text { benefits of studying Hubs and Spokes courses for } \\
\text { students and their future employability. }\end{array}$ \\
\hline & & $\begin{array}{l}\text { Recruit former students who were highly } \\
\text { successful as collaborators to provide face to face } \\
\text { and online mentoring and guidance for students } \\
\text { new to Hubs and Spokes courses. }\end{array}$ \\
\hline \multirow[t]{2}{*}{$\begin{array}{l}\text { 3. Formulate } \\
\text { a vision and } \\
\text { strategy for } \\
\text { direction and } \\
\text { motivation }\end{array}$} & $\begin{array}{l}\text { Create a five minute movie } \\
\text { introducing blended learning } \\
\text { - link to course website. } \\
\text { Scaffolded introduction to } \\
\text { online tools used by students } \\
\text { within each course. }\end{array}$ & $\begin{array}{l}\text { The change that students need to make was given } \\
\text { a name, distinct from blended learning, called } \\
\text { 'Advanced Collaboration for Excellence'. We had } \\
\text { recognised that this was what we were doing as } \\
\text { staff developing courses and this is also what } \\
\text { students needed to do to be successful as students, } \\
\text { but more so to be high achieving engineers. }\end{array}$ \\
\hline & & $\begin{array}{l}\text { Creation of an induction experience that allowed } \\
\text { students to self-assess their needs and undertake } \\
\text { development as required (Moodle Lesson; Figure 3). } \\
\text { The students were required to complete the }\end{array}$ \\
\hline
\end{tabular}




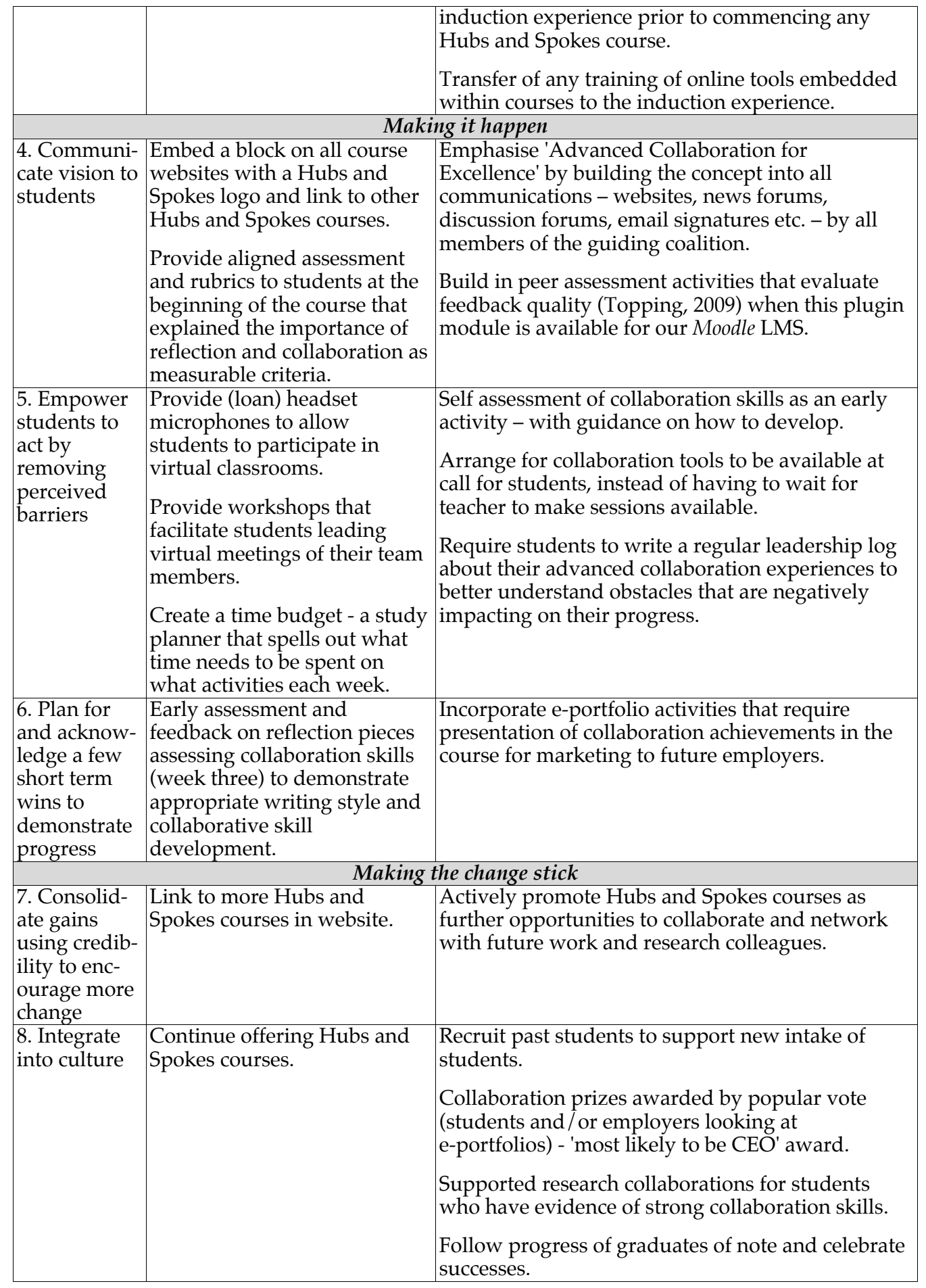




\section{Discussion}

Student engagement is an umbrella concept that looks at the level and quality of student involvement in their learning (Coates, 2006). Institutions are responsible for ensuring that those environments that surround teaching and learning, as well as what happens inside the course, such as aligned assessment (Biggs \& Tang, 2007), do indeed encourage engagement and provide opportunities for learning. The final responsibility for learning, however will always be the students, and their choice to change will be influenced many shifting factors that are out of control of institutions. Regardless of this 'dynamic web of influence' on student engagement (Pascarella \& Terenzini, 1991, p. 458, cited in Coates, 2006), as learning becomes more distributed, as in our Hubs and Spokes project, a greater onus will exist on course development teams to more holistically support students to make the change to engage with new ways of learning and being (Adams et al., 2011).

\section{Supporting students entering cross-institutional blended learning}

Students' expectations on entering a blended learning course need to be actively addressed as a part of the process to ensure misconceptions associated with the term 'blended' (Oliver \& Trigwell, 2005), do not impact negatively on their engagement. For instance, when students sign up for a fully online course, they anticipate the constraints in communication that may exist and balance this loss against the flexibility gained through online study. Similarly, when students sign up for a face to face course, they are aware of the operating constraints (e.g. physically attending sessions) as they enter into the course. However, in a blended course the modus operandi is often unknown. Effort needs to be made to help students understand what the blend will mean to them and how they will need to adapt to the change and why.

Diamond (2005) lists a number of elements which are necessary prerequisites to effective change in higher education environments, and describes how these elements can be put in place using the Kotter model. We were aware of the importance of 'setting the stage' for the shifts in cultural priorities which we were seeking. Kotter emphasises the essential nature of all eight steps in his process (Kotter, 1995). However, the first three steps - creating a sense of urgency, forming a powerful coalition for change, and presenting a vision - are perhaps the most critical in formulating the meaning and motivation which will give the change process its impetus (Fullan, 2007). In implementing these three steps, we were (and still are) laying a solid foundation for change.

\section{Communicating the vision through an induction experience}

In order to communicate this vision of 'Advanced Collaboration for Excellence', and to outline the professional realities which made the changed learning approaches urgent and vital, we designed an induction experience which students were required to complete prior to undertaking Hubs and Spokes courses (Figure 3).

Within this site, we used a number of different motivational strategies to convey our key messages. For example, we presented evidence from engineering professionals describing the modern engineering workplace, we used multimedia resources to demonstrate and explain vital employability skills for young engineers, and we linked to professional bodies (such as Engineers Australia) to outline the relevant 
competencies which our courses support. We also presented the collaboration between UniSA and ANU as an opportunity for the students to benefit from the complementary sharing of expertise between the two institutions.

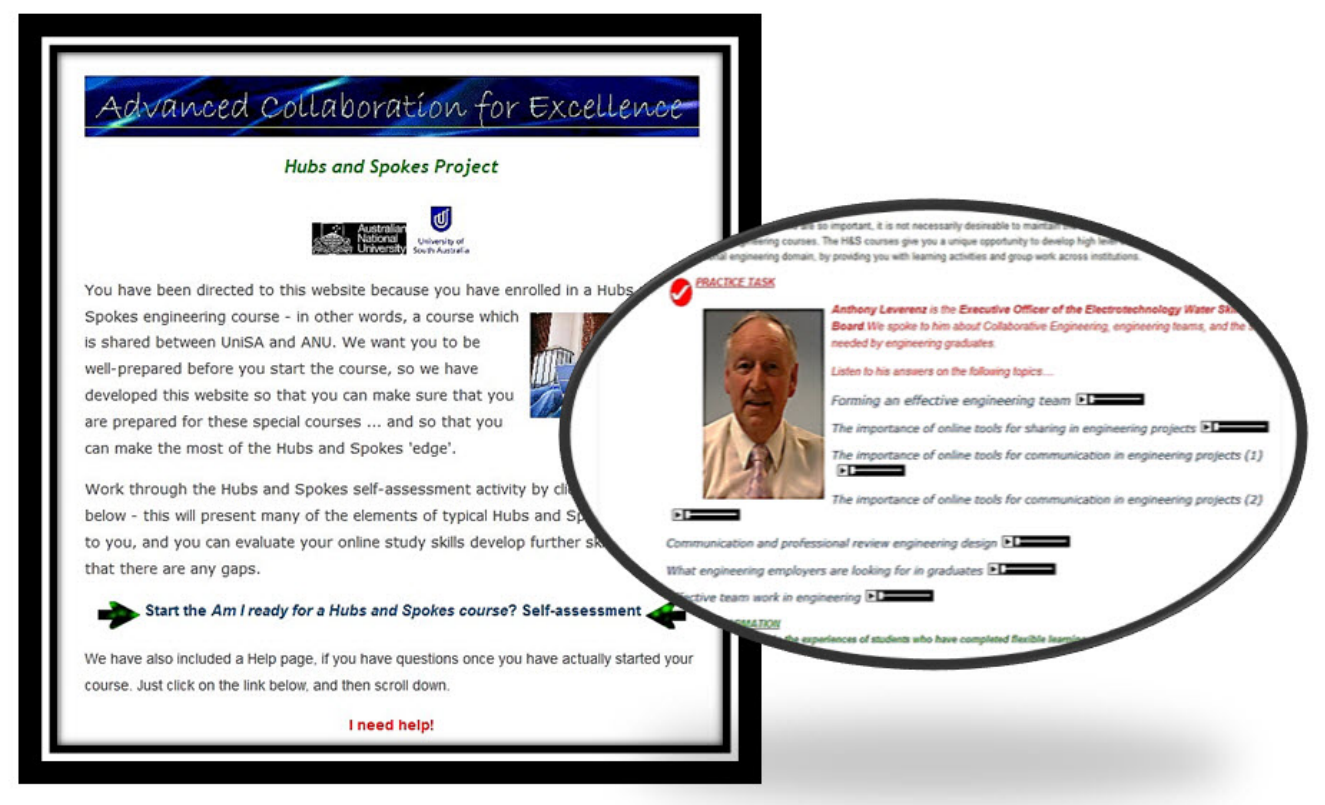

Figure 3: Screen picture from Hubs and Spokes Induction experience

We were very aware of the importance of Kotter's second step - the creation of a powerful guiding coalition. A group of 'committed, reputable and trustworthy supporters who had a strong relationship with others across the organisation' was essential if the changes were to encompass the entire Hubs and Spokes student community (Dawson et al., 2009, p. 71). In the Hubs and Spokes context, this needed to include senior staff and academic staff from both institutions, tutors and student leaders, and practising professionals. We had a number of champions amongst the senior staff, including the ANU Pro Vice-Chancellor for Innovation and Advancement, and the Dean of Teaching and Learning for the Engineering Division in UniSA, and we were able to use the Induction website as a means for passing words of encouragement from these staff to the students.

We were also fortunate enough to have a dedicated project support team which was able to communicate with and offer support to the academic staff and the tutors, to enhance their understanding of the changes which were being implemented and foster their enthusiasm. The support team established communities of practice for the academics, so that they were able to share their approaches and experiences with the newest collaborators in our team. We also approached students who had successfully completed Hubs and Spokes courses, and who were likely to be influential ambassadors for the Hubs and Spokes vision. These students were given the opportunity to act as mentors to other students who were new to this style of teaching and learning, via discussion forums in the Hubs and Spokes Induction. 
Ultimately, we were able to present a strong case for change to the student community, because the change we proposed within our courses reflected a wider change within the professional engineering industry. The collaborative approaches and tools which were embedded in the Hubs and Spokes courses were approaches which professional engineering practice is embracing in the move to collaborative engineering - the systematic approach to integrated engineering design and processes, in which designers, engineers, resources, and models are distributed and work together across the Internet (Kamrani \& Nasr, 2008). This meant that our vision for course delivery was strongly aligned to the type of professional environment in which the students could expect to be working in the future (Sheppard et al., 2008). Moreover, the 'Advanced Collaboration for Excellence' focus of the Hubs and Spokes course design aimed to foster student skills in team work, communication, cooperation and global awareness - skills which engineering employers are increasingly emphasising as more important than technical abilities for professional success.

Leading change has been characteristically a long term process (Kotter 1995; 2007). Unlike industry, however, we have opportunities in higher education to restart the process of change with each new student cohort entering into the Hubs and Spokes learning environment. Annual course offerings and regular evaluation provide opportunities for us to rethink, remake and reinvigorate our culture and vision to better communicate this to students.

By considering change management processes as a part of evaluation, course development teams can be revitalised to see student engagement in blended learning environments in a more holistic way, including in-course and out-of-course experiences and multiple perspectives (Adams et al., 2011). Kotter's eight step principles can help teams to move from the role of academic or instructional designer for a course, to change managers for a way of learning that is more appropriate for students transiting to professional life.

\section{References}

Adams, R., Evangelou, D., English, L., Dias de Figueirdo, A., Mousoulides, N., Pawley, A., Schiefellite, C., Stevens, R., Svinicki, M., Trenor, J. \& Wilson, D. (2011). Multiple perspectives on engaging engineers. Journal of Engineering Education, 100(1), 48-88. http: / / www.jee.org/2011/ January / 04

Amer, Y., Ashraf, M. A., Luong, L., Lee, S. H. \& Wang, Y. C. (2007). A systems approach to order fulfilment using design for six sigma methodology. International Journal of Business and Systems Research, 1(3), 302-316. http: / / dx.doi.org/10.1504/IJBSR.2007.015831

Barnett, R. (2003). Engaging students. In S. Bjarnason \& P. Coldstream (Eds), The idea of engagement: Universities in society. London: Association of Commonwealth Universities.

Biggs, J. \& Tang, C (2007). Teaching for quality learning at university. Open University Press/McGraw-Hill Education.

Blackmore, K., Compston, P., Kane, L., Quinn, D. \& Cropley, D. (2010). The Engineering Hubs and Spokes Project - Institutional cooperation in engineering design and delivery. In Curriculum, technology and transformation for an unknown future. Proceedings ascilite Sydney 2010. http: / / www.ascilite.org.au/conferences / sydney10/procs/Blackmore-concise.pdf

Carneiro, R. (2010). Transforming universities - Section A: New strategies for a culture of change and innovation in universities. In U.-D. Ehlers \& D. Schneckenberg (Eds.), Changing cultures in higher education: Moving ahead to future learning. Chapter 5. New York: Springer. 
Cerbin, W. (1994). The course portfolio as a tool for continuous improvement of teaching and learning. Journal on Excellence in College Teaching, 5(1), 95-105. http: / / celt.muohio.edu/ject/issue.php? $\mathrm{v}=5 \& \mathrm{n}=1$

Chickering A. \& Gamson, Z. (1987). Seven principles for good practice in undergraduate education. American Association for Higher Education Bulletin. http: / / www.aahea.org/bulletins / articles/sevenprinciples1987.htm

Coates, H. (2006). Student engagement in campus-based and online education: University connections. London: Routledge.

Dawson, D., Mighty, J. \& Britnell, J. (2010). Moving from the periphery to the center of the academy: Faculty developers as leaders of change. New Directions for Teaching and Learning, 122, 69-78. http: / / dx.doi.org/10.1002/ tl.399

Diamond, R. M. (2005). The institutional change agency: The expanding role of academic support centres. To Improve the Academy: Resources for Faculty, Instructional and Organizational Development, 2005(23), 24-37. http:/ / www.thenationalacademy.org/readings/instchange.pdf

Fullan, M. (2007). The new meaning of educational change (4th ed.). New York: Teachers College Press.

Guzmán, W. Z., Gely, M. I., Crespo, K., Matos, J. R., Sánchez, N. \& Guerrero, L. M. (2011). Transformation of a dental school's clinical assessment system through Kotter's eight-step change process. Journal of Dental Education, 75(4), 485-95. http: / / www.jdentaled.org/content/75/4/485.abstract

Heathcote, E. \& Taylor, P. (2007). The potential contribution of change management literature to understand and support student transitions. In Enhancing higher education, theory and scholarship: Proceedings HERDSA Adelaide 2007. http: / / www.herdsa.org.au / wpcontent/uploads/conference/2007/ papers/p148.pdf

Kamrani, A. \& Nasr, E. (2008). Collaborative engineering: Theory and practice. New York: Springer.

Kane, L. \& Lonie, A. (2011). Using three flavours of MOODLE to support one project. MoodleMoot AU 2011. Refereed Conference Abstract. http: / / moodlemoot.org.au/mod/page/ view.php?id=54\#LKane

Kotter, J. (2007). Leading change: Why transformation efforts fail. Harvard Business Review, 1 January, 96-103. http: / / hbr.org/ product/leading-change-why-transformation-efforts-failhar/an/R0701J-PDF-ENG; http: / / www.stratafrica.com/media/2a8f73ccf40110beffff80be7f000101.pdf

Kotter, J. (1995). Leading change. Boston: Harvard Business Press.

Learning and Teaching Unit (2010). Teaching Options in learnonline. University of South Australia. http: / / resource.unisa.edu.au / $\bmod /$ resource / view.php?id=3494

Lewin, K. (1952). Group decision and social change. In G. E. Swanson, T. M. Newcomb \& E. L. Hartley (Eds.), Readings in social psychology. New York: Holt, Reinhart \& Winston, 459-473.

McKenzie, J., Pelliccione, L. \& Parker, N. J. (2008). Developing peer review of teaching in blended learning environments: Frameworks and challenges. In Hello! Where are you in the landscape of educational technology? Proceedings ascilite Melbourne 2008. http:/ / www.ascilite.org.au/conferences/melbourne08/procs/mckenzie-j.pdf

National Survey of Student Engagement (2007). Experiences that matter: Enhancing student learning and success. Annual Report 2007. Bloomington: Center for Postsecondary Research. http:/ / nsse.iub.edu/NSSE_2007_Annual_Report/docs/ withhold/NSSE_2007_Annual_Report.pdf 
Oliver, M. \& Trigwell, K. (2005). Can blended learning be redeemed? E-learning and Digital Media, 2(1), 17-26. http: / / dx.doi.org/10.2304/ elea.2005.2.1.17

Pascarella, E. \& Terenzini, P. (1991). How college affects students: Findings and insights from twenty years of research. San Francisco: Jossey-Bass.

Ramsden, P. (2007). Learning to teach in higher education. 2nd ed. London: Jossey Bass.

Salmon, G. (2002). E-activities: The key to active learning. Abingdon: RoutledgeFalmer.

Sheppard, S. D., Macatangay, K., Colby, A., Sullivan, W. M. \& Shulman, L. S. (2008). Carnegie report on educating engineers: Designing for the future of the field. San Francisco: Jossey Bass.

Topping, K. (2009). Peer assessment. Theory into Practice, 48(1), 20-27. http: / / dx.doi.org/ 10.1080/00405840802577569

Trigwell, K. \& Prosser, M. (1991). Improving the quality of student learning: The influence of learning context and student approaches to learning on learning outcomes. Higher Education, 22(3), 251-266. http: / / dx.doi.org/10.1007/BF00132290

Trigwell, K., Prosser, M. \& Waterhouse, F. (1999). Relations between teachers' approaches to teaching and students' approaches to learning. Higher Education, 37(1), 57-70. http: / / dx.doi.org/10.1023/ A:1003548313194

Trounson, A. (2011). Hubs solution for niche courses. The Australian: Higher Education Supplement, 1 June, p. 25. [verified 9 Jan 2012] http: / / www.theaustralian.com.au/highereducation/hubs-solution-for-niche-courses/ story-e6frgcjx-1226066724505

This article received an Outstanding Paper Award at ascilite Hobart 2011, gaining the additional recognition of republication in AJET (with minor revisions). The reference for the Conference version is:

Quinn, D., Amer, Y., Lonie, A, Blackmore, K., Kane, L. \& Pettigrove, M. (2011).

Leading change: Applying change management approaches to engage students in blended learning. In Changing demands, changing directions. Proceedings ascilite Hobart 2011. http: / / www.ascilite.org.au/ conferences/hobart11/ downloads / papers / Quinn-full.pdf

Authors: Dr Diana Quinn, Educational Consultant, Engineering Hubs and Spokes, Division of Information, Engineering and the Environment and Senior Lecturer Academic Development, Learning and Teaching Unit, University of South Australia. Email: Diana.Quinn@unisa.edu.au Web: http: / / people.unisa.edu.au/Diana.Quinn

Dr Yousef Amer, Lecturer, School of Advanced Manufacturing and Mechanical Engineering, Division of Information, Technology, Engineering and the Environment, University of South Australia.

Email: Yousef.Amer@unisa.edu.au Web: http:/ / people.unisa.edu.au/Yousef.Amer

Ms Anne Lonie, Online Educational Developer, Engineering Hubs and Spokes, Division of Information, Technology, Engineering and the Environment, University of South Australia.

Email: Anne.Lonie@unisa.edu.au Web: http: / / people.unisa.edu.au/ Anne.Lonie

Dr Kim Blackmore, Senior Lecturer \& Engineering Hubs and Spokes Sub-Project Leader, College of Engineering and Computer Science,

Australian National University.

Email: Kim.Blackmore@anu.edu.au Web: http:/ / people.cecs.anu.edu.au/user /3494 
Ms Lauren Thompson (nee Kane), Educational Developer, Engineering Hubs and Spokes College of Engineering and Computer Science,

Australian National University. Email: lauren.thompsón@cecs.anu.edu.au

Web: http: / / people.cecs.anu.edu.au/user/3978

Dr Malcolm Pettigrove, Senior Lecturer, Engineering Hubs and Spokes, College of Engineering and Computer Science, Australian National University.

Email: Malcolm.Pettigrove@anu.edu.au

Web: http:/ / people.cecs.anu.edu.au/user/4183

Please cite as: Quinn, D., Amer, Y., Lonie, A., Blackmore, K., Thompson, L. \&

Pettigrove, M. (2012). Leading change: Applying change management approaches to engage students in blended learning. Australasian Journal of Educational Technology, 28(1), 16-29. http:/ / www.ascilite.org.au/ajet/ajet28/ quinn.html 